\title{
Ruset i ord
}

Er det forskjell på å være ruset og beruset, nykter og edru, og skal det hete rusmisbruk eller rusmiddelmisbruk?

Nylig sto det $\mathrm{i}$ avisen at legevakter landet rundt får en strøm av henvendelser fra folk som tror de er blitt dopet ned på byen. Men for det meste finner vi bare alkohol, uttalte leger til avisen (1). I artikkelen sto det videre at $77 \%$ av dem som oppsøkte voldtektsmottaket i Bergen i 2012, fortalte at de hadde vært beruset eller ruset (1).

Vi ser at man skiller mellom å være ruset og beruset - altså samme verbstamme, men det sistnevnte ordet er utstyrt med prefikset be-. Betydningen er forskjellig. I det første tilfellet dreier det seg om narkotika, i det annet om alkohol. Her var det altså usikkerhet om hva de som oppsøkte legevaktene hadde (be)ruset seg på (2).

Distinksjonen ruset/beruset ville ikke blitt oppfattet av avisleserne for 50-60 år siden. I tradisjonell språkbruk heter det bare beruset. Vi har egentlig ikke noe lett tilgjengelig fellesord (2) - selv om vi kan snakke om blandingsmisbruk når en person misbruker både alkohol og narkotika (3).

\section{Nykter og edru}

I ordbøkene er nykter oppført med betydningen «upåvirket av narkotika» (4). Nykter er et av de mange svenske lånordene som har fått fotfeste i norsk slang (5). Normalordet i norsk er edru, men etter at nykter er blitt vanligere, er det utviklet et betydningsskille også her. Nykter brukes i betydningen «ikke påvirket av narkotika», edru i betydningen «ikke påvirket av alkohol» (5).

Helt gjennomført er nok dette skillet ikke. I Tone Trytis fyldige slangordbok står det at nykter også kan bety edru: «jeg gjør det dritbra drita, så tenk deg meg som nykter» (6).

\section{Beruset på nynorsk}

I nynorsk forsøker man å unngå ordformer med prefikset be-. Fornorskningsordbøker, som skal anvise en vei fra bokmål til nynorsk, oppfører be-ord som trenger avløsning. Bedåre skal hete dåre, bekoste skal hete koste osv. (7).

I Rommetveits store fornorskningsordbok står det at beruset bør erstattes av et av følgende: «drukken, full, rusa, (alkohol)påverka; omtåka, påsegla, «på an»; animert, pirum» (8). Det mest nærliggende er kanskje rusa, men da går man glipp av betydningsnyansen som er vokst frem de senere tiårene mellom ruset og beruset (7).

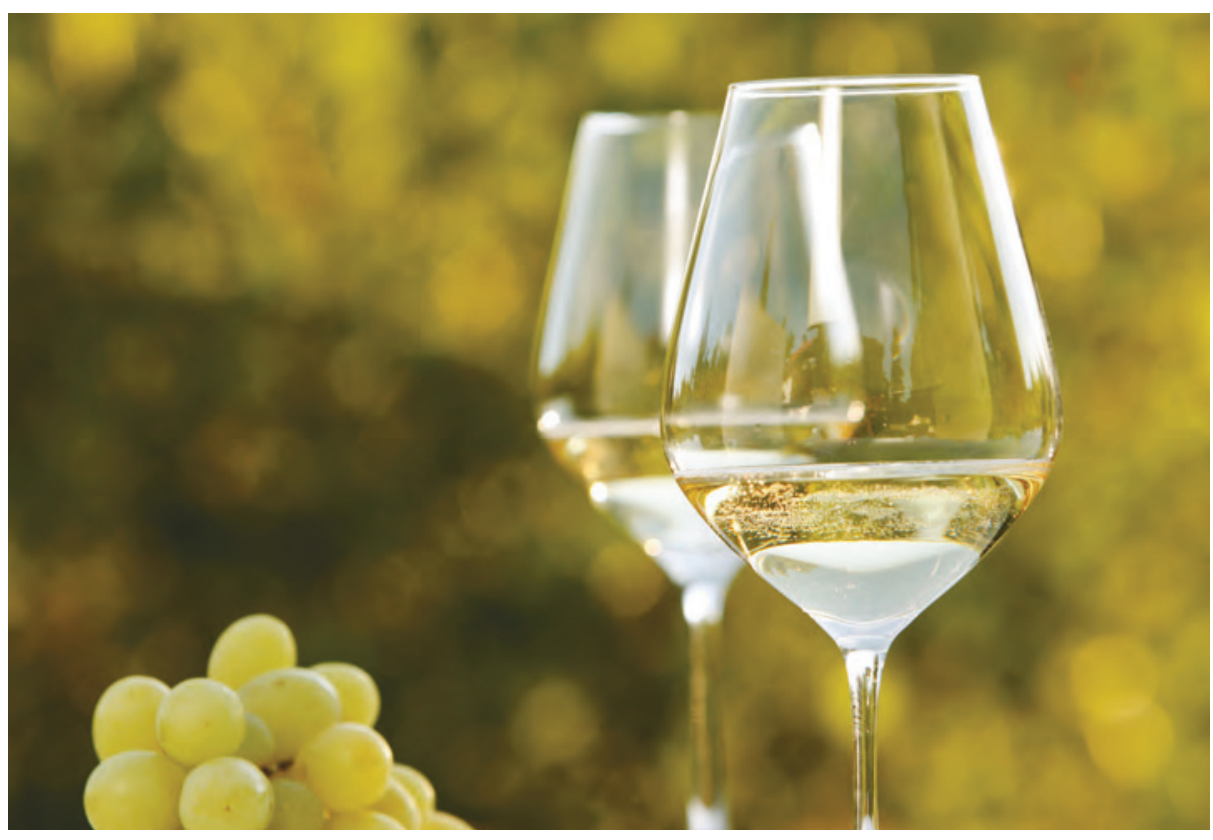

Rusmisbruk eller rusmiddelmisbruk? Hvitvin en varm sommerkveld. Foto: NTB scanpix

\section{Rus- eller rusmiddelmisbruk?}

Og når vi først er i gang med rusterminologi: «Mange har innvendinger mot ordet rusmisbruker. Man (mis)bruker ikke rus, men rusmidler, og rusmiddelbruker eller rusmiddelavhengig er nok å foretrekke,» ifølge Per Egil Hegge (9). «En rusmisbruker må være et menneske som misbruker rus, og det er litt vanskelig å se at det ordet egentlig gir mening. En rusmiddelmisbruker misbruker rusmidler, og språklig sett virker det riktigere» (10).

Hegge har et poeng, men kortformen «rusmisbruk» har tatt et kraftig grep om språket. Vi finner «rusmisbruk» som oppslagsord i Store norske leksikon (11), og det gir over 23000 treff i tekstarkivet Retriever (mot snaut 2000 for rusmiddelmisbruk) (16.8. 2013). Et søk i Tidsskriftets nettutgave viser det samme. «Rusmisbruk» gir 174 treff, mot 57 for «rusmiddelmisbruk» (16.8. 2013).

\section{Erlend Hem}

erlend.hem@medisin.uio.no

Erlend Hem (f. 1970) er dr.med. og assisterende sjefredaktør i Tidsskriftet.
Litteratur

1. Byrkjedal MM. Ikke dop i drinken - du var bare full! VG 13.12.2012: 8

2. Vinje F-E. Ruset / beruset. Finn-Erik Vinjes blogg 21.7.2011. www. finnerikvinje.no/blog/?p=11044 (15.8.2013).

3. Blandingsmisbruk. I: Bokmålsordboka og Nynorskordboka. www.nob-ordbok.uio.no/perl/ ordbok.cgi?OPP=blandingsmisbruk\&ordbok= begge (15.8.2013).

4. Nykter. I: Bokmålsordboka og Nynorskordboka. www.nob-ordbok.uio.no/perl/ordbok.cgi?OPP= nykter\&ordbok=begge (15.8.2013).

5. Vinje F-E. Nykter og ruset - edru og beruset. FinnErik Vinjes blogg 15.1.2012. www. finnerikvinje.no/ blog/?p=13338 (15.8.2013)

6. Tryti T. Norsk slangordbok. Oslo: Kunnskapsforlaget, 2008: 253.

7. Vinje F-E. Prefikset be- er ikke bra! Finn-Erik Vinjes blogg 13.1.2013. www.finnerikvinje.no/blog/ $? p=16706(15.8 .2013)$

8. Beruset. I: Rommetveit M. Med andre ord: den store synonymordboka med omsetjingar til nynorsk. 3. utg. Oslo: Samlaget, 2009: 95.

9. Hegge PE. Språket vårt: Alle livene deres. Aftenposten 11.8.2013: 4. http://tux.aftenposten.no/spraak/ spraak?action=question\&id=5099 (15.9.2013).

10. Hegge PE. Språket vårt: Misbruk. Aftenposten morgen 18.7.2005: 4. http://tux.aftenposten.no/ spraak/spraak? action=question $\&$ id $=1968$ (15.8.2013).

11. Mørland J. Rusmisbruk. I: Store norske leksikon. http://snl.no/rusmisbruk (15.8.2013). 